UDC 343.37: $35.072+341.172+352.07$

DOI https://doi.org/10.32838/TNU-2707-0581/2020.3/03

Nediukha M.P.

V. I. Vernadsky Taurida National University

Podolyaka A.M.

PJSC "Higher Education Institution "Interregional Academy of Personnel Management"

Podolyaka S.A.

PJSC "Higher Education Institution "Interregional Academy of Personnel Management"

\title{
POLITICAL CORRUPTION AS A SOCIAL AND LEGAL PHENOMENON: POLITICAL AND LEGAL MODELS OF COUNTERACTION
}

The article clarifies the essence and proposes a mechanism of identification, prevention of and counteraction to political corruption, which allows considering the latter as a dysfunction of public administration, a sign and result of bureaucratic degeneration of public authorities and local self-government. The threats of bureaucratic and corrupt deformation of democratic governance and related risks and dangers of the sovereign development of the Ukrainian state are emphasized.

Max Weber's theory of rational management is considered as a theoretical and methodological basis for institutional support of anti-corruption in accordance with the living conditions of Ukrainian society in its basic functions: a) adaptation; b) integration; c) goal achievement; d) structure reproduction and tension relief. It is proved that the above creates the necessary conditions to ensure the unity of political will and practical action of public authorities and local governments in accordance with the needs of "network organization" of social and political space of country, strengthening trust and respect, forming partnerships between the government and society as initial means of overcoming the bureaucratic component of corruption offenses.

An institutional model of counteracting political corruption as a theoretical and legal basis for the development of innovative strategies to respond to the challenges and threats of corruption in public authorities and local governments is substantiated. The essence of the institutional model is that, first, the fight against corruption is embedded in the process of management in accordance with the criteria of integrity of the administration, with the meaning, organizational and disciplinary content of rule of law; second, the potential for combating corruption allows to implement the rule of law in the activities of any body of state power and local self-government, where the priority is the task of effective governance in the mode of accessibility and openness online; third, the institutional model of anti-corruption is substantiated as a fundamental basis for the development of innovative models of deterrent anti-corruption in the activities of public authorities and local governments.

The substantive and functional characteristics of innovative model of deterrent anti-corruption at the bodies of the Prosecutor's Office of Ukraine as a kind of the institutional model are presented.

Key words: corruption, political corruption, bureaucracy, bureaucratism, institutional model of counteracting political corruption at state and local self-government bodies, innovative model of deterrent counteraction to political corruption at prosecutor's offices of Ukraine.

Formulation of the problem. Clarification of the essence of political corruption, related challenges and threats to sovereign development is conditioned by a number of circumstances, in particular: a) tasks of modernization of Ukraine in accordance with the chosen European integration course, formation of the rule of law and civil society; b) latest status of Ukraine as one of the most corrupt countries in Eastern Europe, which negatively affects its investment attractiveness and entrepreneurial activity, leads to the merging of its authorities and financial- industrial groups, limiting the potential, resources and opportunities for social change; c) tasks of public administration reform as a kind of modern rule; d) constitutional and legal support for the activities of public authorities and local governments, united territorial communities, understanding the importance of public authorities and local governments as the main actors in the process of social change, positioning in the European and world political and legal space; e) finding satisfactory answers to the challenges, risks and dangers posed by political corrup- 
tion, threatening, above all, the existence of Ukrainian statehood; f) deterioration of the rating of perception of corruption in Ukraine, which currently ranks 126th out of 180 countries on the basis of its spread, rootedness in public authorities and local self-government [1]; f) low level of trust of civil society institutions in the government: $83 \%$ of Ukrainians believe that the fight against corruption in the highest echelons of power is not successful [2].

The weakness of real fight against political corruption is also identified by a number of circumstances, first of all, the return to the Ukrainian legal and political space of the somewhat forgotten term "politically motivated justice" and the associated threat of introduction of corresponding practice of justice, violation of the principles of rule of law as well as initiation by European institutions of the question of suspension of visa-free regime with Ukraine for regression in combating corruption [3].

Analysis of recent research and publications. Effective counteraction to political corruption, related challenges and threats is possible, as noted in the scientific literature, by using the theoretical and methodological potential of a systems approach that allows to ensure the unity of action of relevant actors embodied in political will, legislative regulation and proper support of initiatives and measures to combat corruption by civil society institutions and individual citizens of the country [4, p. 21]. The study of issues of anticorruption, their identification as a political and legal phenomenon is carried out by representatives of various branches of the humanities, including jurisprudence [5], political science [6], public administration [7].

In Ukraine, a number of anti-corruption bodies are known to investigate corruption by senior officials: the National Anti-Corruption Agency (NACA), the Prosecutor's Office of Ukraine (POU), the National Anti-Corruption Bureau of Ukraine (NACBU), the Specialized Anti-Corruption Prosecutor's Office (SACPO), the State Bureau of Investigation (SBI), The Supreme Administrative Court of Ukraine (SACU), the National Agency of Ukraine for Detection, Investigation and Management of Assets Obtained from Corruption and Other Crimes (ARMA), the efficiency of which is extremely low [8].

The essence of the concept of "corruption" (from the Latin word corruptio - seduction, bribery, corruption) is ambiguous, because scientists include in its content criminal acts, illegal activities, elements (signs) of organized crime, etc., thus identifying it with bribery, extortion, protectionism, nepotism, deception, waste of budget funds, abuse of power, etc. The nature, character and peculiarities of the formation of this socially and politically threatening phenomenon, its bearers and manifestations, the mechanism of functioning, etc. are also insufficiently clarified. Accordingly, political and legal, social, personnel, organizational, disciplinary means of preventing, neutralizing and combating this social evil require additional study [4, p. 21]. It is also noted that "the most affected in terms of latent lobbying is the legislative process in the field of privatization, financing, lending, banking, licensing, distribution of funds" $[9$, p. 14] as well as taxation and customs.

The issues related to clarifying the essence of political corruption, the mechanisms of its formation and spread, effective strategies - institutional and innovative - of counteracting and responding to the challenges and threats posed by it, especially in public authorities and local government are also insufficiently studied [10].

Works of V. Hvozdetskyi, M. Melnyk, M. Mykhalchenko and O. Mykhalchenko, Ye. Nevmerzhytskyi, V. Solovyov, M. Khavronyuk, M. Weber, M. Voslensky, S. Huntington, T. Parsons, F. Fukuyama and others made a significant intellectual contribution to understanding of the essence of corruption in the process of social reform, improvement of the content of legal norms including in the activity of higher bodies of state power and local self-government. Thus, in particular, S. Huntington proved that corruption threats are especially strong in the context of modernization changes of young sovereign states, which are characterized primarily by the weakness of public administration: increasing threats to its bureaucratization can create states of socio-political disorder, mass frustration, protest moods, riots and revolutions. This refers to, in particular, the processes of democratic change, in which social mobilization precedes the development of political institutions [11, p. 76]. Rapid spread of political corruption, its scale is due to the dynamics of modernization change, the emergence of new sources of power and wealth, new classes as well as changes in the political and legal systems, their weakness. The conflict between modern and traditional norms and values allows to neglect both the former and the latter for the sake of "triumph" of personal interest as absolutely higher-priority and at the same time determinative in daily activity of the civil servant [11, p. 69-70]. In this case, political corruption means "behavior of public officials that deviates from generally accepted norms in order to achieve a private goal", is implemented by carrying out certain political actions in exchange for economic benefits, thereby converting public goals into private, personal ones $[11$, p. $69,73,75]$. "Laws governing trade, customs 
duties, taxes as well as popular and lucrative activities such as gambling, prostitution and the production and sale of alcohol become the biggest incentives for corruption", Huntington rightly said. "Because of this, in a society where corruption is widespread, the adoption of strict laws against corruption only creates new opportunities for it" [11, p. 72].

In the scientific literature, it is believed that the essence, nature and direction of modernization changes can subordinate the behavior of officials to two fundamentally different strategies that are alternative - to serve the public good or their private interests. It is obvious that these strategies and the appropriate behavior are the result of personal choice of a politician or civil servant, which is based on moral and ethical virtues, value priorities, legal norms or selfish calculation, personal selfishness and so on. Accordingly, the risks of corruption as well as nepotism (nepotism, compatriot solidarity and clannishness) are determined by both objective and subjective factors, the dynamics of social change, are the result of the distinction between public welfare and private interest [11, p. 71], thus being an official's conscious choice of the line of conduct - virtuous or illegal, corrupt. In this case, the emphasis is laid, given Ukraine's European integration choice, the task of adapting domestic legislation to the legal norms of the European Union member states, on the importance of ensuring international standards of public governance [12] as the main criteria for the legal and regulatory support of combating corruption in public authorities [13], which, as it is known, are embodied in theories of public management [14], "service state" [15], "network administration" [16], "e-government" [17] etc.

The newest source of corruption in Ukraine, generated directly by modernization, is represented by the newly formed social groups and clans, which protect their wealth, privileges, statuses and roles, as well as resources - political, power, media, etc., accumulated, as a rule, illegally. The incompleteness of process of modernization changes of Ukrainian society, the uncertainty of development strategy have a negative impact on functioning of state and local governments, management activities of officials, essence and nature of adopted laws and resolutions, lead to the merging of power and capital, etc. Oligarchic clans, shadow business structures, imposing their private interests on the government, create risks of "seizure, purchase and privatization of the state" [18, p. 7-8], lead to the substitution of state, national interests for their private or corporate counterparts.

Instead, the traditional source of corruption in Ukraine is associated with the activities of officials of the former party, state and Soviet nomenklatura (from the Latin word nomenclatura - list of names), which under the conditions of sovereign development adapted to the conditions of sovereign development, transformed in accordance with the tasks of modernization changes, holding corresponding positions in public authorities and local governments [4, p. 25, 26].

Setting objectives. The purpose of the article is to define the essence of political corruption, to develop political and legal means of its identification, prevention and counteraction as a social and legal phenomenon that threatens the Ukrainian statehood. Accordingly, it seems appropriate to substantiate an institutional model of combating political corruption as a theoretical and legal basis for responding to challenges and threats of bureaucratic degeneration of the management apparatus of public authorities and local government as well as to outline the main characteristics of innovative model of anti-corruption at the bodies of the Prosecutor's Office of Ukraine as a kind of the institutional model.

Presentation of the main research material. As it is known, management processes cannot be effectively carried out without rational organization of human labor, without a special, appropriately prepared apparatus of specialists - bureaucracy (from the French word bureau - office and the Greek one kratos - power, domination, literally office power, the power of management apparatus) with its main characteristics: a) existence of written rules that are considered rational; b) division of labor; c) hierarchical structure; d) professionalism of its members; e) depersonalization (fulfillment of professional roles regardless of personal desires and needs); f) discipline and predictability of behavior; g) attempts to impose their own interest on society as a universal interest, etc [19].

The classical theory of rational management system (bureaucracy) [20], substantiated by M. Weber, is based on the fundamental principle of politicaladministrative dichotomy as a means of identifying actors - politicians and civil servants, whose vocation is to ensure the organic unity of process, single in its essence, of generation and discussion of statebuilding ideas, making decisions and their effective implementing, the super-task of which is social benefit - individual or collective. This allows not only to ensure an organic unity - content and functional of various subjects of public administration, but also to purposefully establish management activities as a holistic process, starting with the production, discussion, selection and dissemination of ideas, their indoctrination (mass, corporate, individual one) to 
effective execution of decisions, their implementation in practice [21, p. 112-117].

The above unity of various parts of essentially single public administration process is due to both the objective conditions of life of a transitional society and the subjective factors, which is embodied primarily in the priority of political decisions over economic ones, mandatory nature of their implementation by state officials as ones who act in accordance with the constitutional requirements, the legislation of country, are competent, legally protected, ideologically and politically neutral, loyal to the political leaders employees with the appropriate statutory status and public control over their professional activities. This rational organization of management activities has also, unfortunately, a shadow side: the cadre bureaucracy, which is appointed rather than elected by the people, tends to act contrary to national priorities, relying on its own interests as supposedly determinative and self-sufficient at the same time.

However, at a certain stage of social change, first of all, under the conditions of modernization development, bureaucracy as a progressive social phenomenon turns into its opposite - a closed system, unable to effectively renew itself by means of exchange with the social environment of its daily functioning. Rational behavior, being subordinated to personal, usually selfish interests, becomes an end in itself; the means becomes the goal; loyalty turns into conformism. Accordingly, the tendencies of depersonalization of relations, formal attitude toward work intensify; attempts to isolate itself from the external environment and its pressure, to cover everything with a veil of secrecy, etc. become more and more obvious. Rational organization is replaced by a group monopoly of officials to the performance of management functions and the ways of exercising power. At the heart of this monopoly are the subjectivist aspirations of officials as a narrow social caste, which the apparatus tries to pass off as the national interest, to identify it with the public good. Bureaucracy as a rationally constructed hierarchical management structure turns into bureaucratism - a system of distorted political, economic and social governance that is based on separation (alienation) of the omnipotent, closed apparatus from society, interests, needs and demands of its citizens; it is power exercised through an extensive network of officials, police apparatus and administration $[4$, p. 26]. Accordingly, bureaucratism is a dysfunction of the activities of public authorities and local self-government, a kind of disease of administration as a manifestation and result of the subordination of state and national interests to mercenary, subjectivist-oriented aspirations, orientations, expectations and actions. The main signs of bureaucratism are the alienation of officials from the object of government - the people, caste isolation and cold indifference to the interests of fellow citizens and society as a whole [4, p. 26].

The peculiarity of current socio-political situation in Ukraine is that the traditional foundations of society are destroyed on the basis of its modernization, but political and legal projects adequate to the new tasks are not proposed: there are no national programs to reform the Ukrainian society; there is lack of charismatic, nationwide leaders; not only the prospect of society's development, but also the proper continuity in the actions, first of all, of the executive branch have been lost. The judicial system does not meet the challenges of time, either [4, p. 22].

So, what are the threats associated with the activities of domestic bureaucracy? First, it is the attempt to privatize the government with the prospect of its transformation into a bureaucratized one, the threats of privatization of state in accordance with the established corporate culture and the self-interest of authorities which opposes the national interest. Accordingly, the main threats to the deformation of public administration in terms of its bureaucratization are associated with access to power and the ability to own, use and dispose of it as property for one's own or corporate benefit. In this case, the rapidity and scale of bureaucratization of power are determined by the level of dialogue between the government and the people, possible opposition and even resistance of civil society institutions, the degree of subordination of administrative apparatus to the tasks of ensuring the functioning of vital functions of society, the delegation of professionally trained and nationally loyal staff to the power structures as well as the statecraft of bureaucracy, its devotion to national interests. The processes of bureaucratic degeneration of state authorities and local selfgovernment cannot but be affected by radical changes in the value orientations of Ukrainians, peculiarities of their behavior, way of life, and so on. However, there is no doubt about the fundamental inconsistency of culture of deformed system of government, the scale of its spread and the threats it produces, with the mentality of Ukrainian people, its established customs and traditions, state-building intentions and so on. The constitutional and legal definition of the people as a source of power is not equivalent to the essence of power itself, which can take various forms of its legitimate existence and actual implementation. Power is known to be identified not only as a result of public expression of will: in accordance with the current legislation, managers are recommended, delegated and appointed to appropriate positions in public 
authorities and local governments. The above suggests that significant avoidance of bureaucratic corruption degeneration, deformation of public authorities and local self-government is possible by introducing an institutional model of identifying, preventing and combating political corruption as one that meets the objectives of the above bodies in the transitional state of Ukrainian society. Although Ukraine does not lack, as it is known, various anti-corruption strategies developed at different levels - scientific, expert, state, territorial, etc. - they have a common shortcoming: they are separate, isolated, unable to offer a holistic system of institutional support to combat corruption in accordance with the current dynamics of process of social changes. There are attempts to correlate the scale of corruption with the degree of fulfillment of requirements of law without taking into account their substance that is represented by real life process, strategic priorities of Ukrainian society, which largely explains the ineffectiveness of legal norm as a means of regulating public relations [22, p. 192-194].

The essence of the institutional model of anticorruption is that the fight against corruption: a) is embedded in the process of administrative, right exercise and law enforcement activities in accordance with the criteria of integrity of administration apparatus and the substance of rule of law; b) allows to implement legal norms in the activities of any body of state power and local self-government, where the priority is the task of effective governance, including on the basis of anti-corruption (administrative apparatus with its professional and moral-ethical characteristics, regulatory and legal support of activities and its public control - in the mode of accessibility and openness online), c) is a fundamental basis for the development of innovative models of deterrent anti-corruption in the activities of public authorities and self-government as components of an institutional (national) anti-corruption strategy.

The theory of rational management of M. Weber, which allows to coordinate the management activities of apparatus both "vertically" and "horizontally" in accordance with the conditions of functioning, the state of life activities of society and the prospects of its modernization growth according to the basic functions of: a) adaptation; b) integration; c) goal achievement; d) structure reproduction and tension relief [23, p. 37-40], can serve as a theoretical and methodological basis of the institutional support for combating corruption. The conceptual potential of theories of "new public management" [24], "good governance" [25], "new civil service" [26], which, supplementing and concretizing the classical model of rational organization of management of Max Weber, propose a number of innovations that result in the institutionalization of civil service, its formation as a holistic, orderly, structured system with corresponding functions, methods and mechanisms of public, social, legal and organizational support, offers peculiar means of counteracting bureaucratic degeneration of the administration apparatus and, at the same time, theoretical and legal foundations of the institutional model. Thus, for example, the postulates of new state management with its latest requirements - the network principle of organization, political and social partnership, competitiveness, priority of temporary professionally trained teams, staff exchange between government and business, decentralization, service delivery, performance monitoring and payment based on the results of performance according to target indicators, etc. - allow to consider state and municipal administration as well as civil society organizations as structural elements of modern government and a public institution at the same time. The above creates the necessary conditions to ensure the unity of political will and practical action of authorities in accordance with the needs and demands of "network organization" of social and political space of country, strengthening trust and respect, forming partnership principles of cooperation as a starting point to overcome bureaucratic corruption [27]. In this case, the social essence of public administration as a component of institutional identification, prevention of and counteraction to political corruption is conditioned by the concept of the "new civil service" with its striving for universal human values, common good, dialogue and cooperation, fair law enforcement and the practice of moral and ethical "worship" to society.

Content characteristics of public administration as a legal institution are determined by its constitutional jurisdiction, legality and law-and-order, the rule of law.

At the same time, the structural unity of components of public administration "vertically" (subordination) and "horizontally" (coordination) in their subordination to the implementation of social development functions (systemic quality) as well as ensuring content and functional interaction of the above institutions as a systemic whole characterize it as an organizational institution. In this case, it is obvious that the level of development of components of public administration, of the content and functional support of their implementation in the life activity of Ukrainian society is significantly different: the legal and organizational institutionalization is dominant and decisive at the same time, while the social and public orientation is in its infancy. 
This also cannot but affect the legislative consolidation of institutional characteristics of civil service, its impact on the life of state, society, citizens and country as a whole.

The above structural units - despite their unequal importance as components of public administration together form an institutional model for combating political corruption which can be considered as a theoretical and legal basis for developing innovative strategies to prevent and combat corruption at bodies of state power and local government. Accordingly, the innovative model of deterrent anti-corruption at the bodies of prosecutor's office should be built and substantiated in accordance with the main provisions of institutional model a determinant from a theoretical, methodological and legal point of view.

The institutional model of combating corruption is such that it is oriented to the formation of: a) a new type of management class as a modern bureaucracy and a way of governing - professional, open, patriotic, strategically oriented; b) a rational, in terms of goal, type of relations of interaction between the state and society as partners; c) partnership relations by gradually overcoming the still dominant attitudes of affective and traditional rationality in political activity, thus defining strategically defined priorities. At the same time, lack of politically defined goals of the process of social change creates the correspond- ing type of management bureaucracy, and this determines the essential characteristics, generic features of authorities, especially their weakness, corruption, painful situationality and strategic uncertainty. In this case, there is noticeable lack of policy of "realization of rational goals" based and implemented in accordance with the national priorities, embodied in legal norms, of process of social change, decentralization of public administration, formation of government as a modern type of political and legal management.

The above priority steps include, of course, human (personnel) and regulatory support, preparation of relevant anti-corruption legislation: legal norms should be based on the principles of "integrity" and implemented transparently - in an accessible and open "online" mode of the activities of public authorities and local self-government.

Thus, institutional counteraction to political corruption is implemented as the process of identification, establishment and regulation of legal relations in the field of activities of public authorities and local governments, civil society organizations in accordance with current legislation, social, organizational and disciplinary support of their activities as public actors striving for implementing the basic functions of life activities of society in their subordination to strategically defined development goals, establishing civilized standards of the level and quality of life.

\section{References:}

1. Corruption Perception Index 2019 / Transparency International: the global coalition against corruption. Berlin : "Transparency International" International Secretariat, 2020. 30 p.

2. URL: https://www.dw.com/uk/83-vidsotky-ukrayinciv-ne-bachat-uspixiv-v-borotbi-z-korupciyeyu-opytuvannya/ a-52557209].

3. URL: https://prm.ua/drugiy-sezon-politichno-dramatichnogo-serialu-diplomat-pidbiv-pidsumki-politichnihdosyagnen-zelenskogo/.

4. Недюха М. Корупція як соціально-правовий феномен. Юридична Україна. 2014. № 8. С. 21-27.

5. Подоляка С.А. Теоретико-практичні основи адміністративно-правового забезпечення протидії корупції в органах прокуратури України : монографія. Київ : МП «Леся», 2018. 435 с.

6. Михальченко М., Михальченко О., Невмержицький $Є$. Корупція в Україні: політико-філософський аналіз : монографія. Київ : ТОВ «Видавництво Дельта», 2011. 615 с.

7. Соловйов В.М. Запобігання і протидія корупції в державному управлінні України : монографія. Київ : Інститут законодавства Верховної Ради України, 2012. 508 с.

8. URL: https://glavcom.ua/publications/chorna-karma-ryaboshapki-663884.html?utm_source=gravitec\&utm medium=push\&utm campaign= $=0 \mathrm{D} 0 \% \mathrm{BF} \% \mathrm{D} 0 \% \mathrm{BE} \% \mathrm{D} 0 \% \mathrm{BB} \% \mathrm{D} 1 \% 96 \% \mathrm{D} 1 \% 82 \% \mathrm{D} 0 \% \overline{\mathrm{B}} 8 \% \mathrm{D} 0 \% \mathrm{BA} \% \mathrm{D} 0 \% \mathrm{~B} 0$.

9. Недюха М.П., Федорін М.П. Лобізм як соціально-політичний феномен: сутність і засоби впливу. Віче. 2010. № 4. С. 12-15.

10. Amundsen I. Political Corruption: An Introduction to the Issues. Bergen : Chr. Michelsen Institut, 1999. $32 \mathrm{p}$.

11. Гангтінгтон С. Політичний порядок у мінливих суспільствах / пер. $з$ англ. Тарас Цимбал. Київ : Наш формат, 2020. $448 \mathrm{c}$.

12. The Worldwide Governance Indicators. World bank. URL: http://info.worldbank.org/governance/wgi/ index.asp.

13. Hughes O.E. Public Management and Administration: USA: $3^{\text {rd }}$ Revised ed. New York ; Palgrave Macmillan, 2003. 303 p. 
14. Bovaird T. Public Governance: Balancing Stakeholder Power in a Network Society. International Review of Administrative Sciences. 2005. Vol. 71. № 2. P. 217-228.

15. Denhardt R.B., Denhardt J.V. The new public service: Serving rather than steering. Public Administration Review. 2000. Vol. 60. № 6. P. 549-559.

16. Worldwide Trends in the Human Development Index 1980-2010 / International Human Development Indicators. 2011. URL: http://hdr.undp.org/en/data/trends/1980-2010.

17. Torres L., Pina V. Changes in Public Service Delivery in the EU Countries. Public Money \& Management. 2002. Oct. -Dec. P. 41-48.

18. Hellmann J.S., Jones Geraint, Kaufmann D. Seize the State, Seize the Day State Capture, Corruption and Influence in Transition. 2000. Sept. Word Bank Policy Research Working Paper. 2000. № 2444 : The Word Bank. $41 \mathrm{p}$.

19. Маркс К., Энгельс Ф. К критике гегелевской философии права. URL: http://www.civisbook.ru.

20. Weber M. Gesammelte Aufsatze zur Wissenschaftslehre. Berlin, 1922. S. 404.

21. Elliott Jacques. A General Theory of Bureaucracy. USA : New York, Halsted Press, 1976. 412 p.

22. Недюха М.П. «Суспільні відносини» та «соціальні відносини» як поняття політико-правової науки. Наукові записки Інституту політичних і етнонаціональних досліджень імені І.Ф. Кураса НАН Украӥни. 2018. № 2 (94) (березень-квітень). С. 188 D. 200.

23. Недюха М.П. Правова ідеологія українського суспільства : монографія. Київ : МП «Леся», 2012. 400 с.

24. Dunleavy P., Hood C. From Old Public-Administration to New Public Management. Public Money \& Management. 1994. Vol. 14. Issue 3. P. 9-16.

25. Heritier P., Silvestri P. Good government, Governance, Human complexity. Luigi Einaudi's legacy and contemporary societies. Firenze, 2012.340 p.

26. Denhardt R.B., Denhardt J.V. The New Public Service: Serving Rather Than Steering. Public Administration Review. 2000. Vol. 60. Issue 6. P. 549-559.

27. Brian R.F., Jos C.N. Raad-Schelders. Mastering Public Administration: from Max Weber to Dwight Waldo. 2nd ed. Washington : CQPress, 2008.

\section{Недюха М.П., Подоляка А.М., Подоляка С.А. ПОЛІТИЧНА КОРУПЦІЯ ЯК СОЦІАЛЬНО-ПРАВОВЕ ЯВИЩЕ: ПОЛІТИКО-ПРАВОВІ МОДЕЛІ ПРОТИДІЇ}

У статті з'ясовано сутність $і$ запропоновано механізм ідентифікаиії, запобігання та протидї політичній корупиії, який дає змогу розглядати останню як дисфункцію державного управління, ознаку й результат бюрократичного переродження органів державної влади та місиевого самоврядування. Наголошено на загрозах бюрократично-корупчійної деформації демократичного врядування й пов'язаних із ним ризиків і небезпек суверенного розвитку української держави.

Теорія рачіональної організачії управління Макса Вебера розглянута як теоретико-методологічна підвалина інституиійного забезпечення протидї корупиї̈ відповідно до умов життєдіяльності українського суспільства за базовими його функиіями: а) адаптаџії; б) інтеграції; в) иіледосягання; 2) відтворення структури $і$ зняття напруження. Доведено, що зазначеним створюються необхідні умови для забезпечення єдності політичної волі та практичної дії органів державної влади й місцевого самоврядування відповідно до потреб «мережевої організації» сочіального та політико-правового простору країни, утвердження довіри й поваги, формування партнерських відносин влади й суспільства як вихідних засобів подолання бюрократичного складника корупчійних правопорушень.

Обгрунтовано інституційну модель протидії політичній корупиії як теоретико-правову основу розроблення інновачійних стратегій реагування на виклики й загрози корупиї в органах державної влади та місиевого самоврядування. Сутність інституційної моделі полягає в тому, що, по-перше, протидія корупиії закладена в процес управлінської діяльності відповідно до критеріїв доброчесності апарату управління, змістового, організаційного та дисииплінарного наповнення норми права; по-друге, потенціал протидії корупиії дає змогу реалізувати норму права в діяльності будь-якого органа державної влади та місиевого самоврядування, де пріоритетними є завдання ефективного врядування в режимі доступності й відкритості оп line; по-третє, інституиійна модель протидї корупиії обгрунтована як засаднича підвалина розроблення інновачійних моделей стримувальної протидї̈ корупиії в діяльності органів державної влади та місиевого самоврядування.

Викладено змістові й функиіональні характеристики інноващійної моделі стримувальної протидії корупиії в органах прокуратури України як різновиду інституційної моделі.

Ключові слова: корупиія, політична корупчія, бюрократія, бюрократизм, інституційна модель протидії політичній корупиії в органах державної влади та місцевого самоврядування, інноваційна модель стримувальної протидії політичній корупиї̈ в органах прокуратури України. 